\title{
A NEW PAPER-MAKING CREMATOGASTER FROM THE SOUTHEASTERN UNITED STATES. ${ }^{1}$
}

\section{By William Morton Wheeler.}

More than thirty years ago the late Prof. George F. Atkinson described and figured a large, elongate elliptical paper nest which he took to be the work of our common acrobat ant, Crematogaster lineolata Say. ${ }^{2}$ The structure, "about eighteen inches long by twelve inches in circumference at greatest diameter" was discovered by $H$. A. Brown in the marshes bordering Broad Creek, Hyde County, N. C., and was "built several feet from the ground on a bush." The material was. "of a light gray color, much like that of the nest of the white-faced hornet," but was darker internally, almost black in some places. Atkinson believed that the Crematogaster, instead of building in its usual manner under stones or logs, where it not infrequently covers the walls of its chambers with a variable amount of dark-colored carton, had adopted the arboreal habit as a "singular adaptation" to living in a swamp. As I saw no reason to question the correctness of his identification of the ant, I have on two or three occasions expressed the same opinion. $^{8}$

About a year ago Dr. E. F. Bigelow sent me a photograph and fragments of a large paper nest found by Mr. J. Willis Youngs at Fort Myers, Fla., together with some of the ants that had constructed it. Dr. Bigelow subsequently published the photograph with a few notes. ${ }^{4}$ The nest as shown in the photograph is much damaged but must have been originally more than a foot in length. A study of the ants shows that they represent an undescribed species, closely related to $C$. lineolata but easily recognizable as distinct. I feel reasonably certain from an examination of the carton and a comparison of Atkinson's and Bigelow's figures that both nests were built by the same species of ant.

Very recently Dr. W. M. Mann sent me specimens of the same

1 Contribution from the Entomological Laboratory of the Bussey Institution, Harvard University. No. 157.

2 Singular Adaptation in Nest-making by an Ant, Cremastogaster lineolata Say. Amer. Natural. 21, 1887, pp. 770-771, Pl. 26.

3 The Habits of the Tent-building Ant (Crematogaster lineolata Say). Bull. American Mus. Nat. Hist. 22, 1906, p. 15; Vestigial Instincts in Insects and other Animals. Amer. Journ. Psychol. 19, 1908, p. 4.

A Very Interesting Study of Ants. Guide to Nature 11, March 1919, p. 270. 
Crematogaster from a paper nest found by E. S. Snyder on a willow tree, two feet above the ground, on Paradise Key, Fla., and on critically examining the large series of Crematogaster that have been accumulating in my collection for more than twenty years, I find specimens of the same ant and of a yellow variety from several localities in Florida, Georgia and North Carolina. Prof. J. H. Comstock gave me Atkinson's original photograph of the nest described from North Carolina. I reproduce it in the hope that the more modern half-tone process may bring out the texture of the carton even more clearly than in the original article. I also reproduce a photograph of the Paradise Key nest kindly loaned me by Dr. Mann.

The new Crematogaster and its variety are herewith described.

Crematogaster atkinsoni sp. nov.

(Fig. 1 b.)

Worker. Length 2.5-3.3 mm.

Similar to the typical lineolata Say, but smaller, the latter measuring from 3 to $4 \mathrm{~mm}$., with the thorax, especially the proand mesonotum more slender, the promesonotal suture more indistinct, the mesonotum more flattened and with more indistinct longitudinal carina. Head smaller and proportionally narrower; the frontal groove much less distinct. Antennal scapes longer, reaching about twice their greatest diameter beyond the posterior border of the head. Epinotal spines decidedly longer, straight, more slender and more acute, longer than the base of the epinotum and as long as the distance between their insertions. They are widely divergent and directed less backward and somewhat more obliquely upward than in the typical lineolata.

Surface smooth and shining, the thorax above without traces of the distinct puncturation and rugulation of lineolata, except the base of the epinotum, which is longitudinally rugulose. Mesopleuræ opaque, finely and densely punctate. Epinotal declivity very smooth and shining as are also the upper surfaces of the petiole and postpetiole (opaque or subopaque in lineolata). Head and gaster highly polished, except the mandibles and cheeks which are subopaque and finely striate, and the clypeus, which is indistinctly striate and somewhat less shining than the front and vertex. 
Pubescence much as in the typical lineolata, but the erect hairs are sparser, the appressed hairs on the legs shorter. The hairs on the antennal scapes, however, are longer, more abundant and oblique.

Color like that of the typical lineolata, castaneous with black gaster, the latter sometimes paler at the base; antennæ and legs more reddish brown, with the middle portions of the femora and tibiæ and the tip of the last antennal joint piceous or blackish.

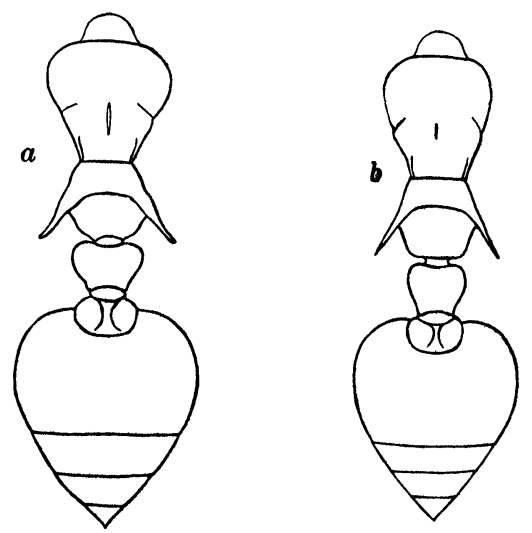

Figure 1. $a$, Thorax and abdomen of worker Crematogaster lineolata Say; $b$, $b, C$. atkinsoni sp. nov.

Some specimens have the head and thorax more blackish, with the mandibles, cheeks, clypeus, tarsi, articulations of the legs, thorax, petiole, and postpetiole reddish brown or deep red.

Described from several workers from Fort Myers, Fla. (J. W. Youngs) which may be regarded as the type-locality. I possess other specimens taken in the following localities in the same state: Titusville (Amer. Mus. Nat. Hist.); Crescent City (Van Duzee); Jacksonville (Mrs. A. T. Slosson); Paradise Key; (E. S. Snyder) and Tallahassee.

C. atkinsoni var. helveola var. nov.

Worker. Like the typical form of the species, except in color. Brownish yellow, legs slightly paler; posterior half of gaster and sometimes also the upper surface of the head pale brown.

Female (deälated). Length $6.5 \mathrm{~mm}$. 
Much smaller than the female of the typical lineolata, which measures 8-8.5 mm. Head more rectangular and fully as long as broad (broader in lineolata, with more rounded sides and posterior corners). Epinotal spines reduced to stout teeth as in lineolata but shorter and slightly more deflected. Metanotum (postscutellum) much less protuberant in profile.

Surface of body smoother and more shining, covered with fine, sparse, piligerous punctures; mandibles and anterior half of head longitudinally striate, mandibles rather opaque.

Hairs whitish, apparently less abundant than in lineolata, pubescence much the same. Hairs on the scapes shorter and less conspicuous than in the worker.

Colored like the worker, but the scutellum, an anteromedian and an elongate spot on each side of the mesonotum and the whole gaster brown; each segment of the latter with a narrow, transverse, dark brown band near the posterior margin. Mandibles red, with black apical margins.

Male. Length about $3 \mathrm{~mm}$.

Smaller than the male of the typical lineolata, which measures 4-4.5 mm. Head blackish; thorax, petiole and postpetiole chocolate brown; antennæ and legs, mandibles and gaster brownish yellow, the dorsal surface of the gaster darker. Wings white, with colorless veins and stigma. Head and gaster somewhat shining, thorax more opaque. Pilosity much less developed than in the male of lineolata.

Described from several workers and males and a single female taken by Prof. J. C. Bradley in the Okefenokee Swamp, Ga. (type locality). The Rev. P. J. Schmitt sent me many years ago several workers which he had taken at Lake Worth, Fla., and Belmont, N. C.

C. atkinsoni is very closely allied to C. ashmeadi Mayr and to lineolata subsp. locviuscula Mayr. Both of these forms have the surface of the body smooth and shining, though in lacviuscula and its vars. clara Mayr and californica Emery the thorax is distinctly sculptured. C. ashmeadi is, however, smaller than atkinsoni in both worker and female phases, and the worker has the epinotal spines reduced to stout distinctly incurved teeth. The epinotal spines of the typical looviuscula are shorter and more sinuate than in atkinsoni and the vars. clara and californica are larger, of a very 
different color and with much more opaque and sculptured thorax and pedicel.

After renewed study of the North American Crematogasters in my collection, and of most of the forms in the field, I incline to regard those that have been cited as subspecies of lineolata by Emery and myself, namely pilosa Pergande, loviuscula Mayr, coarctata Mayr and opaca Mayr, as worthy of specific rank. This is merely a return to the position of Mayr, who described the three latter forms as separate species. The complete list of Crematogasters known to inhabit America north of Mexico, and including the two described above, would run as follows:

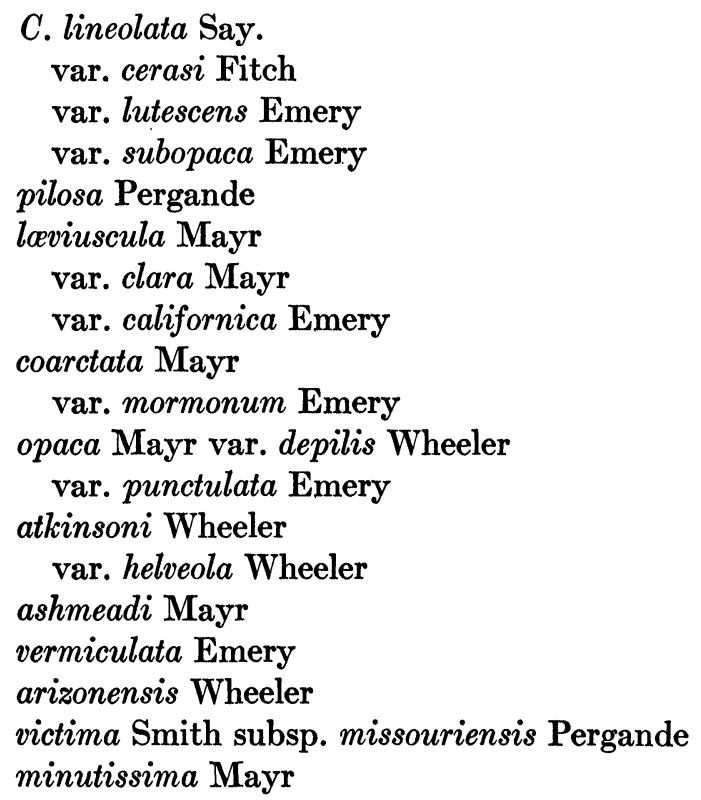

Additional data on the habits of $C$. atkinsoni would be of considerable interest. Consultation of the atlas shows that, with the exception of Belmont, N. C., all the localities cited for this ant and its variety are near the sea-shore, where the species seems to be confined to swamps, or, at any rate, to regions subject to periodic inundation. This may account for the fact that its nest has been so seldom seen, although the ant may be a rather rare relict of a time when the Southeastern States had a more tropical climate. 
Be this as it may, we must now abandon the view that the large paper nests occasionally found in North Carolina and Florida are merely so many sporadic or local adaptations of $C$. lineolata colonies to living in flooded districts, and must regard them as the work of a peculiar species whose method of nidification is unlike that of any other Nearctic ant though very similar to that of many of the tropical species of Crematogaster.

Explanation of Plates V and VI.

Plate V. Nest of Crematogaster atkinsoni sp. nov. from the original photograph of Prof. G. F. Atkinson published in 1887. (American Naturalist, Vol. 21, Pl. 26.)

Plate VI. Nest of Crematogaster atkinsoni sp. nov. from Paradise Key, Florida (Collection W. M. Mann). 


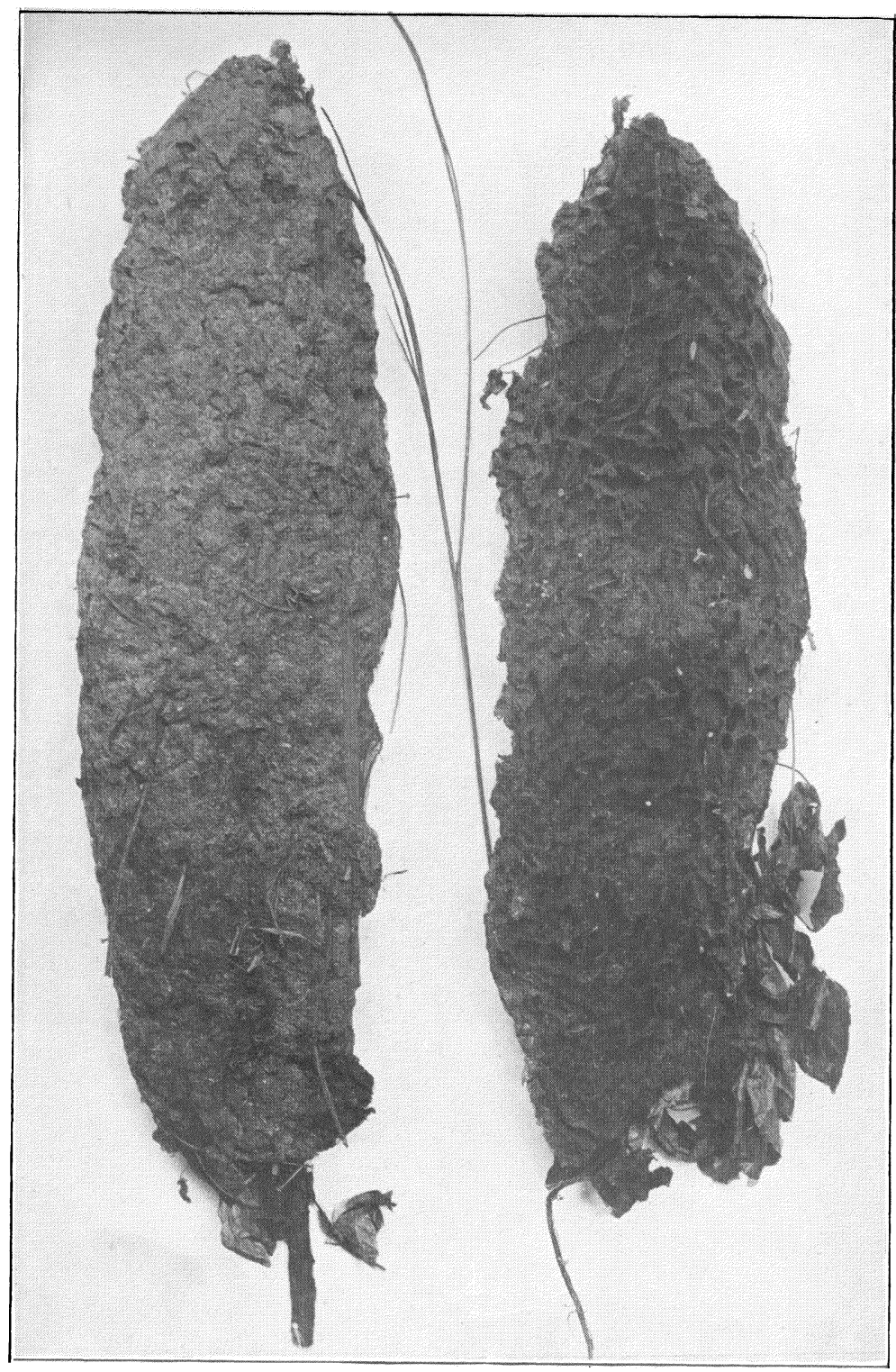




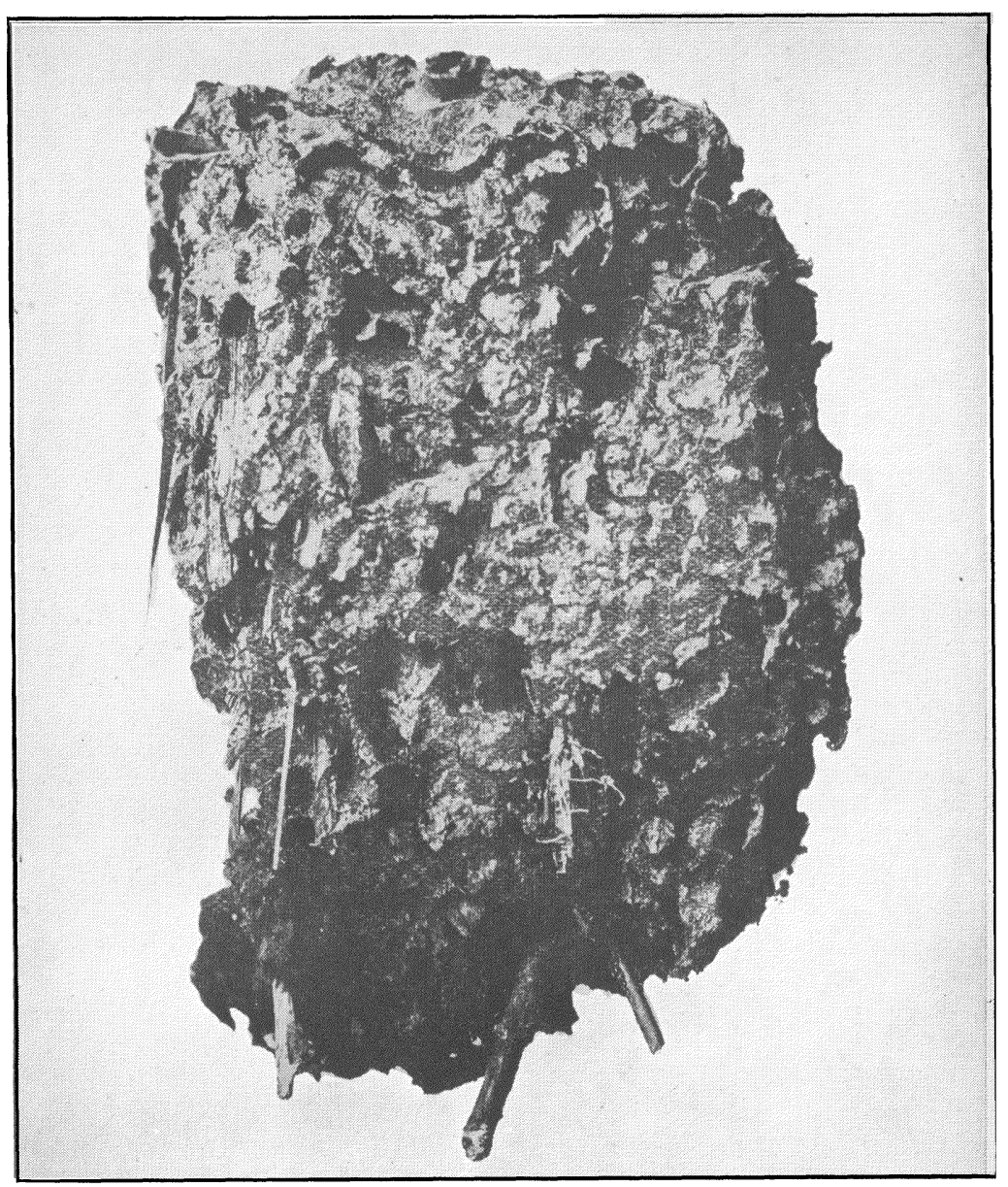

Wheeler-Paper-making Crematogaster 

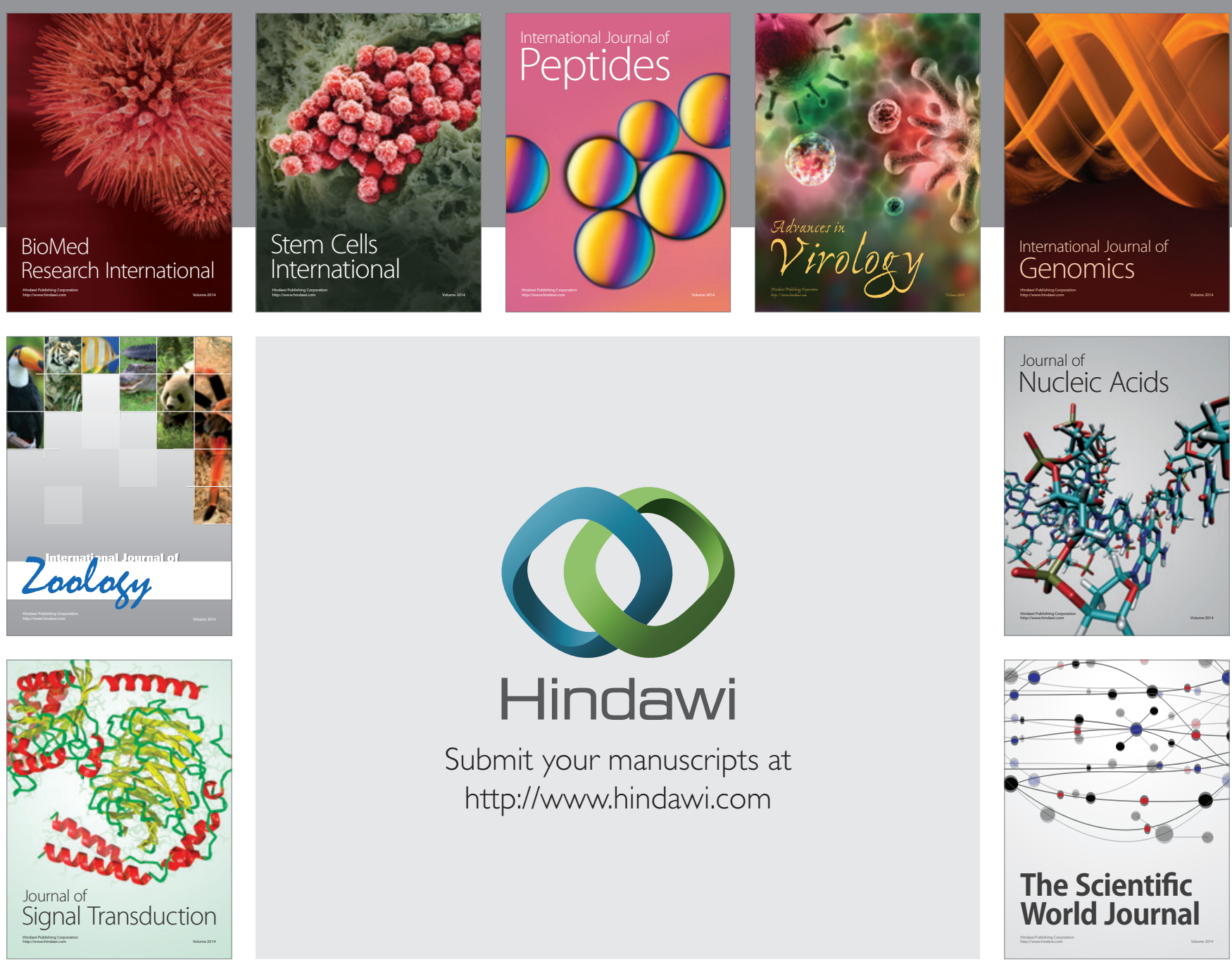

Submit your manuscripts at

http://www.hindawi.com
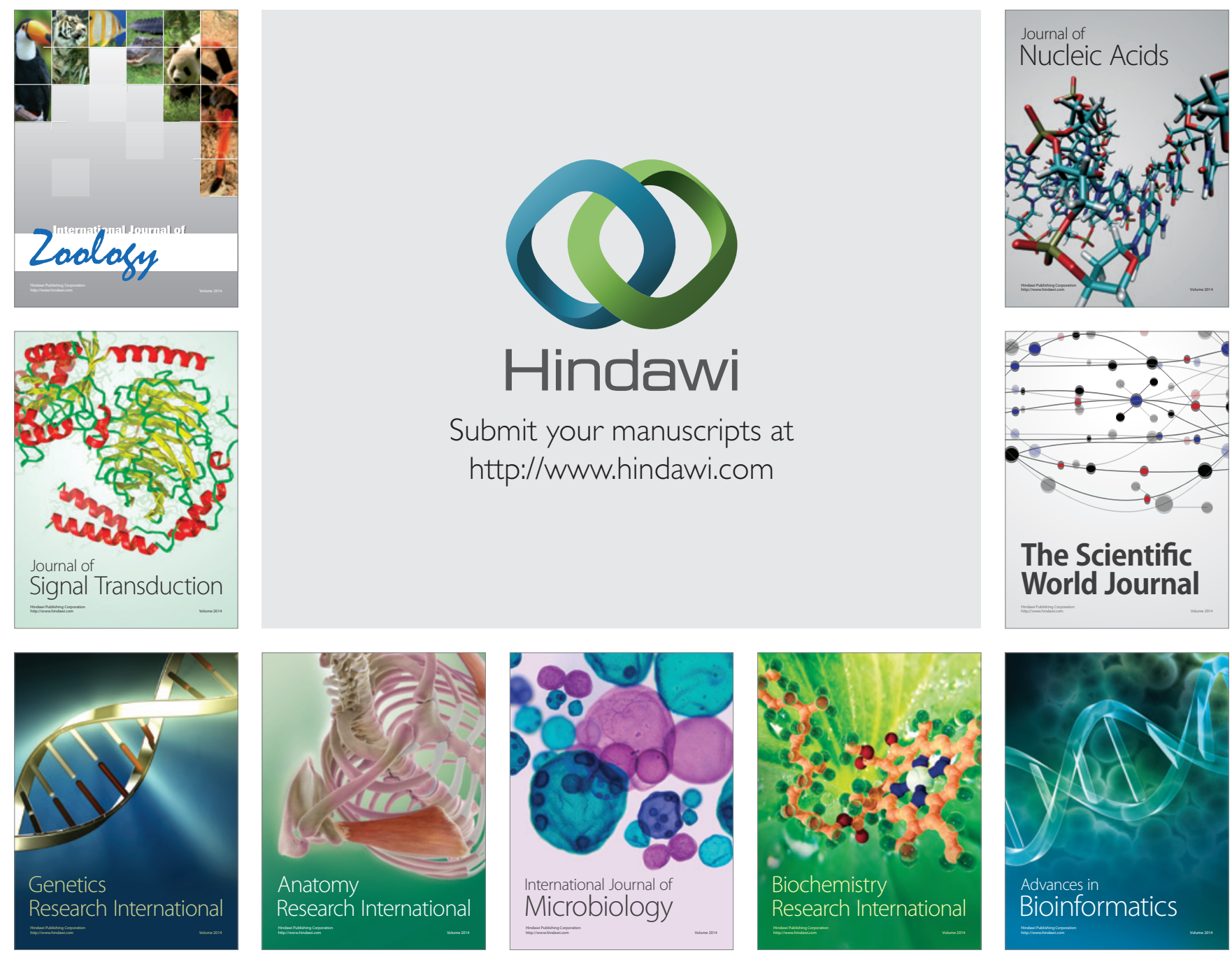

The Scientific World Journal
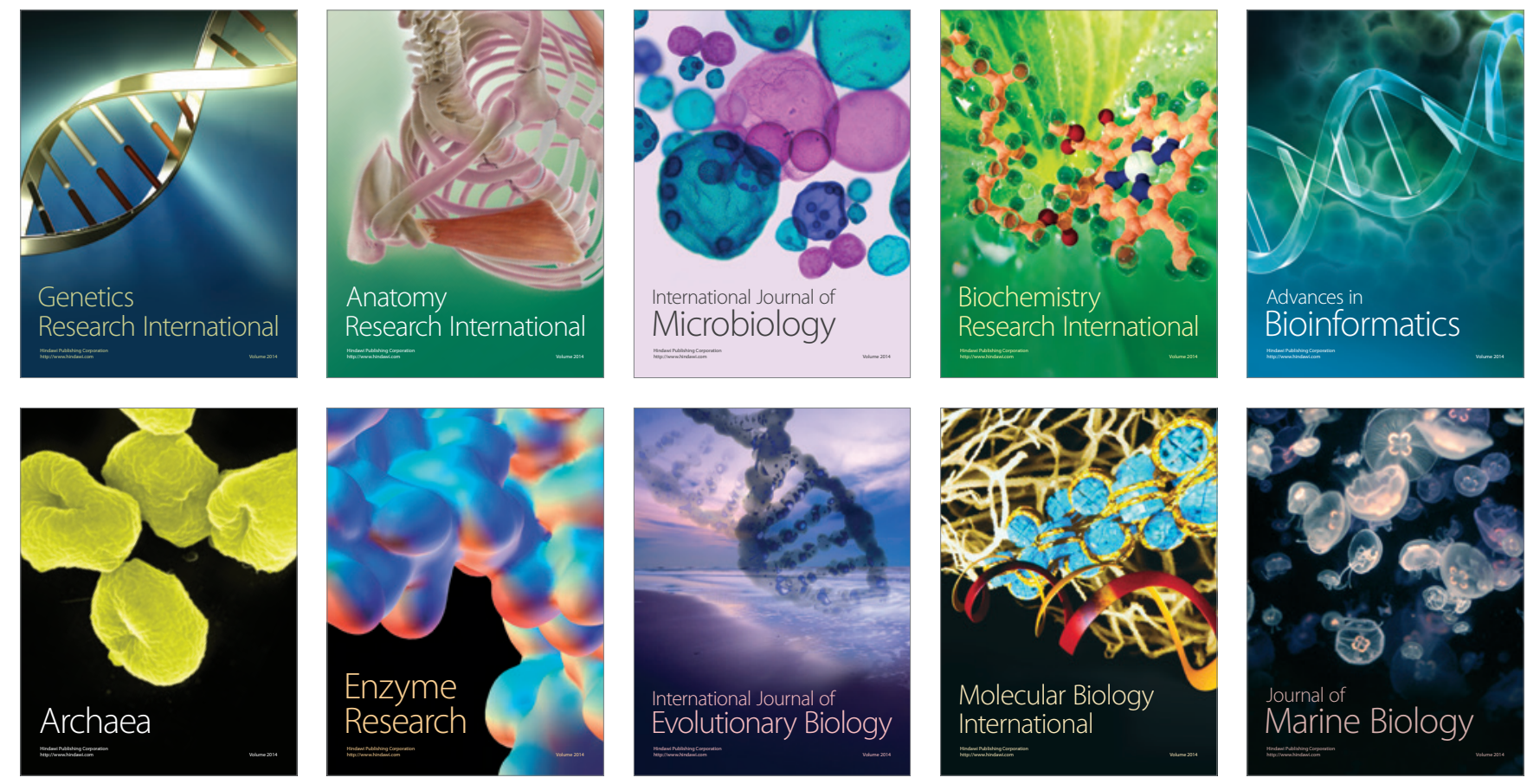